\title{
SOCIALIAI ATSIRIBOJUSIŲ MOKINIŲ İGALINIMO BENDROJO LAVINIMO MOKYKLOJE TEORINĖS PRIELAIDOS
}

\author{
Laima Kyburienè $\dot{1}^{1,3}$, Donatas Senikas ${ }^{2}$, Žibuoklè Senikienè $\dot{3}^{3}$ \\ Vytauto Didžiojo universitetas ${ }^{1}$, Kauno medicinos universitetas ${ }^{2}$, Kauno kolegija ${ }^{3}$, \\ Kaunas, Lietuva
}

\begin{abstract}
Laima Kyburienė. Vytauto Didžiojo universiteto doktorantė. Kauno kolegijos Jonušo Radvilos fakulteto Edukologijos katedros vedėja. Mokslinio tyrimo kryptis — socialiai atsiribojusių mokinių socialinis igalinimas bendrojo lavinimo mokyklose, socialiai integralios mokymosi aplinkos klasėje kūrimas.
\end{abstract}

\section{SANTRAUKA}

Tyrimu siekta išsiaiškinti, kokios socialiai atsiribojusiu mokiniu igalinimo bendrojo lavinimo mokykloje galimybès. Pabréżiama mokyklos gyvenimo pilnatvès ir darnos ideja, iš esmès lemianti mokyklos, kaip visumos, poveikị individo dvasinei raidai. Metai, praleidžiami mokykloje, suteikia vaikui galimybę mokytis dangybès nauju dalyku, vis geriau pažinti aplinkiní pasauli, igyti daug draugu. Dangeliui vaiku, pradedančiu lankyti mokykla, ateitis atrodo viliojanti ir pilna ¿̇vairiausiu galimybiu, viska, atrodo, ¿̇manoma pasiekti ir nugalèti. Mokykliniame amžiuje vaikui labai svarbu mokykla ir draugystè su bendraamžiais.

Socialiai atsiriboję mokiniai iš pirmo žvilgsnio išoriškai atrodo sèkmingi (yra pažangūs, puikiai elgiasi), bet jie turi emociniu sunkumu: bijo atsakinèti prie lentos, atsakinèjant žodžiu ju rankos dreba, jie kalba labai tyliai, verksmingai, visada stengiasi būti nuošaliau. Tokie vaikai labai nerimastingi, jie pernelyg prastai save vertina, yra labai pažeidžiami ir dèl per didelio nerimastingumo, drovumo negali tinkamai išreikšti savo gebèjimu (Fantuzzo et al., 2005).

Aptarus socialinio atsiribojimo ir socialinio igalinimo sqvokas, daugiausia demesio sutelkiama í socialiai atsiribojusiu mokiniu igalinimo bendrojo lavinimo mokykloje galimybes, norint teoriškai išanalizuoti ir empiriškai pagristi minètu mokiniu igalinimo bendrojo lavinimo mokykloje modeli. Pastebima, kad socialiai atsiribojusiu mokiniu igalinima turètu inicijuoti: psichologiness-pedagogines komandos nariai kartu su socialiniu pedagogu, ¿̇traukdami dalyku mokytojus, klasiu auklètojus; turètu büti rengiami planai, užsibréžiami tikslai, o visus proceso dalyvius turi sieti vieningai organizuota veikla. Pabrėžiama tai, kad socialiai atsiribojusiu mokiniu igalinimo bendrojo lavinimo mokykloje paveikiais proceso dalyviais galètu būti socialiai aktyvūs bendraamžiai. Aktyviu mokiniu bendravimas su socialiai atsiribojusiais mokiniais yra veiksmingesnis sprendžiant itakos klausimq nei suaugusiuju.

Raktažodžiai: socialinis atsiribojimas, socialinis igalinimas, igalinimo modelis.

\section{IVADAS}

$\breve{\mathrm{S}}$ ių laikų edukologija gyvenimą mokyklose ima traktuoti kaip ypatingą ugdymo šaltini. Nekyla abejoniu, kad gyvenimas mokyklose yra vienas iš svarbiausių asmens dvasinio ugdymo veiksnių. Apimdamas daugelị kitu psichoedukaciniu veiksnių, mokyklinis gyvenimas atlieka vientiso, arba visiško, veiksnio funkciją. Kartu iškeliama mokyklos gyvenimo pilnatvès ir darnos idèja, iš esmès lemianti mokyklos, kaip visumos, poveiki individo dvasinei raidai. Metai praleidžiami mokykloje, suteikia vaikui galimybę mokytis daugybės naujų dalykų, vis geriau pažinti aplinkini pasauli, igyti daug draugų. Daugeliui vaikų, pradedančių lankyti mokyklą, ateitis atrodo viliojanti ir pilna ivvairiausiu galimybių, viską, atrodo, imanoma pasiekti ir nugalèti. Mokyklinio 
amžiaus tarpsniu vaikui labai svarbu mokykla ir draugystė su bendraamžiais. Socializacijos procese vaikai priklauso savitai bendraamžių subkultūrai, išmoksta atlikti tam tikrus socialinius vaidmenis ir prisitaikyti prie aplinkos. Jei aplinka yra nepalanki, ir vaikas auklejimo procese patiria smurta, meilès stoką, neapykantą ir pan., jis dažnai depresuoja, jaučia neapykantą visam pasauliui, visai visuomenei ir užsisklendžia. Socialiai atsiriboję mokiniai iš pirmo žvilgsnio išoriškai atrodo sèkmingi (yra pažangūs, puikiai elgiasi), bet jie turi emocinių sunkumų: bijo atsakinèti prie lentos, atsakinėjant žodžiu jų rankos dreba, jie kalba labai tyliai, verksmingai, visada stengiasi būti nuošaliau. Tokie vaikai labai nerimastingi, jie pernelyg prastai save vertina, yra labai pažeidžiami ir dèl per didelio nerimastingumo bei drovumo negali tinkamai išreikšti savo gebejjimų (Sondaite, Žukauskienè 2004; Fantuzzo et al., 2005; Fantuzzo, 2006; Malinauskiené, Žukauskienè, 2007).

Pastaraisiais metais daugelis vakarų šalių mokslininku socialini atsiribojimą vaikysteje nurodo kaip potencialų rizikos veiksnị vėlesniais amžiaus tarpsniais prisitaikant ir adaptuojantis visuomenėje (Gerhold et al., 2002). Socialiai atsiriboję ar uždari, labai kuklūs, drovūs vaikai nurodomi kaip rizikos grupè vėlesniais amžiaus tarpsniais ịveikiant nerimą ir depresiją (Ladd, Troop-Gordon, 2003; Rubin, Coplan, 2004; Ladd, 2006; Ladd et al., 2006), taip pat jie lèčiau prisitaiko, jiems sunkiau pasirūpinti savo profesine karjera (Cornwall, Perlman, 1990). Taigi svarbu apibrèžti socialinio atsiribojimo sąvoką, suprasti socialinio atsiribojimo priežastis ir numatyti galimas socialiai atsiribojančiujų raidos pasekmes, ugdymo ir pagalbos jiems galimybes.

Remiantis Vakarų šalių mokslininkų tyrimais, socialinio atsiribojimo sąvoką galima apibūdinti kaip tam tikrą vaiko ar paauglio elgsenos modelị, pagal kuri vaikas nuolat vengia bet kokios sąveikos su bendraamžiais ar jų grupėmis jam gerai pažistamomis situacijomis. Socialinis atsiribojimas (uždarumas) čia suprantamas kaip mokinio elgsena, išreiškianti subjektyvią būseną bei požiūri i bendravimą, ir yra susijusi su tam tikrais dalyvavimo socialinèje veikloje jausmais, mažinančiais aktyvumą, paralyžiuojančiais valia, nuteikiančiais pasyviai gynybai. Žmogui būdinga priešinga natūrali savybè — noras bendrauti, nes ji nulemta asmenybès socialinių bendravimo poreikių: poreikio priklausyti kokiai nors grupei ir poreikio būti gerbiamam (savigarbos). Socialinio atsiribojimo sąvoka neapima suvaržyto, drovaus elgesio ir tam tikro uždarumo tokiomis situacijomis, kurių metu vaikui ar paaugliui tenka bendrauti su jam visiškai nepažistamais suaugusiaisiais ir bendraamžiais.

Aptikta daugybè empirinių tyrimų, atliktų Vakarų šalių mokslininkų, siekiančių geriau suprasti socialiai atsiribojusius mokinius ir teoriškai pagristi socialinio atsiribojimo tipus (Copan et al., 1994; Coplan, Rubin, 1998; Nelson et al., 2000; Hart et al., 2000). Šie tyrimai atskleidè socialinio atsiribojimo tipus ir tai, kaip skirtingi elgesio modeliai apibūdina skirtingus socialinio atsiribojimo tipus, aiškiau susiejo socialinio atsiribojimo raišką su sociopsichologiniais rodikliais, apibūdinančiais socialinio prisitaikymo lygi.

Mokslinès literatūros analizè rodo, kad socialinio igalinimo sąvoka tiek Vakarų šalių, tiek Lietuvos edukologijos mokslininkų darbuose yra taikoma retai.

„Dabartinès lietuvių kalbos žodynas“ (1993) nurodo žodžio ,igalinti“" reikšmę - tai „leisti“ kažką daryti. Vadinasi, socialinis igalinimas, remiantis šia samprata, reikštų leisti būti socialiai aktyviu. Šiuo požiūriu tokia reikšmè nepakankamai atskleidžia socialinio igalinimo sampratą, kadangi jau vien tik mokinio prièmimas i mokyklą leidžia, suteikia teisę jam bendrauti, t. y. būti socialiai aktyviu. Todèl šio tyrimo metu socialinis igalinimas bus nagrinèjamas kitu aspektu.

Igalinimas apima delegavimą, individualią atsakomybę, savarankišką sprendimų prièmimą ir tikejjimo galèjimu efektyviai veikti jausmą (Thorlakson, Murray, 1996).

Igalinimas suvokiamas kaip jėgos arba galios suteikimas tam tikrai veiklai atlikti. Šią galią autoriai traktuoja dvejopai: jie išryškina santykini ir motyvacini galios komponentus. Pirmasis išreiškiamas kaip galios valdyti ir kontroliuoti kitus žmones suteikimas (Koberg et al., 1999). Tai galètú būti siejama su tam tikrais igaliojimais ar delegavimu. Motyvacinis komponentas daugiau išreiškia žmogaus galią daryti ittaką ne kitiems žmonėms, bet situacijoms. Remiantis pastaruoju komponentu, žmogaus galia apibrèžiama kaip jo tikejjimas savo gebejjimais mobilizuoti motyvaciją, pažintinius išteklius ir veiksmus, leidžiančius kontroliuoti konkretų ivyki ir akcentuoja tikejjimą tuo, kad jo pastangos leis tinkamai veikti. Pastarasis požiūris nesietinas su delegavimu. Tai daugiau susiję su priežasčių, skatinančių bejègiškumą, identifikavimu ir jų eliminavimu. Igalinimo sąvoką siejant su motyvacija, turètų būti akcentuojama vidinè, o ne išorinè motyvacija (Thorlakson, Murray, 1996). 
Kai kurie mokslininkai igalinimo sampratą sieja su žiniu turejimu. Žinios tampa galingumo priemone, kadangi leidžia pamatyti tiesą apie toki pasaulit, koks jis yra (Usher et al., 1997). Minèti mokslininkai jëgą mato kaip negatyvų konstruktą, prievartos ir neteisètos kontrolès šaltini, kurios eliminavimas leidžia individams realizuoti jiems būdingą racionalumą, laisvai save išreikšti ir visapusiškai realizuoti. Šio tyrimo metu i jègą žiūrima ne kaip i negatyvų dalyka, ne kaip i draudimą ar represiją, bet kaip i aktyvų ir proaktyvų dalyką jègos suteikimas (igalinimas) kuria galimybes, kitaip tariant, igalinimu ,dalykai padaromi imanomais" (Usher et al., 1997).

D. Lipinskienè (2002) išskiria du igalinimo sampratos aspektus:

- Igalinimas siejamas su individu, t. y. igalintu laikomas tas individas, kuris turi galios veikti taip, kaip reikalinga. Ši galia yra igyjama, kai individas turi tiek laisvę bei galimybę veikti skirtingai ir kas kartą geriau, tiek reikalingas ir tinkamas situacines žinias. Tuomet keliamas jo tikejimas savimi, savo gebejimais ir tikèjimas sẻkminga veikla kintančioje aplinkoje. Visgi akivaizdu, kad vienas individas to padaryti negali — jam reikalinga išorine parama. Todèl pasidaro aiški ir kita igalinimo aplinkybè — išorinès aplinkos kūrimas.

- Igalinimas siejamas su išorine aplinka, dažniausiai su sąlygu, kurios apima atsakomybès lygi, delegavima, autonomija, sudarymu organizacijoje.

Taigi igalinimas gali būti matomas iš dvieju perspektyvų. Pirma, igalinimas kaip siekimas padidinti individo pasitikejimą savimi suteikiant jam reikalingą informaciją, išteklius, žinias. Antra, igalinimas kaip tinkamos aplinkos, kuri skatina individą plètoti savo žinias ir kompetenciją, kūrimas, sudarant sąlygas reikštis autonomijai, laisvei, atsakomybei ir pan.

Pateiktuose apibrèžimuose galima išskirti bendrą bruožą - igalinimas skiriamas tam tikrai veiklai gerinti, suteikiant vienokią ar kitokią paramą. Igalinimas tiriamos problemos atveju suprantamas kaip siekimas gerinti socialini dalyvavimą, suteikiant socialinę (aktyvaus bendravimo ir bendradarbiavimo) paramą, leidžiančią didinti individo pasitikejjimą savimi, sukuriančią tinkamą aplinką, kuri skatina individą plètoti savo žinias ir kompetenciją, dalyvauti socialinèje veikloje.

Išsakyti teiginiai paskatino atlikti tyrimą, kurio metu buvo keliama problema - kokia mokymo / mokymosi aplinka yra tinkama socialiai atsiribo- jusių mokinių socialiniam igalinimui bendrojo lavinimo mokykloje.

Tyrimo objektas - socialiai atsiribojusiu mokiniu igalinimo galimybė bendrojo lavinimo mokykloje.

Tikslas - teoriškai išanalizuoti ir empiriškai pagrissti socialiai atsiribojusių mokinių igalinimo bendrojo lavinimo mokykloje modeli.

\section{Uždaviniai:}

1) aptarti socialinio atsiribojimo ir igalinimo sampratas;

2) remiantis atlikta teorine analize ir empirinio tyrimo (ekspertinio vertinimo) rezultatais aptarti socialiai atsiribojusiu mokiniu igalinimo galimybes bendrojo lavinimo mokykloje;

3) mokslinès analizès ir ekspertinio vertinimo pagrindu sukonstruoti hipotetini socialiai atsiribojusių mokinių igalinimo bendrojo lavinimo mokykloje modeli.

\section{TYRIMO METODIKA IR ORGANIZAVIMAS}

Tyrimo tikslui pasiekti buvo taikyti šie metodai:

- mokslinès literatūros analizè, kuria buvo siekiama išnagrinèti galimas teorines socialiai atsiribojusių mokinių igalinimo prielaidas;

- ekspertų metodas, kuriuo buvo siekiama išanalizuoti, ivvertinti ir patobulinti parengtą socialiai atsiribojusių mokinių igalinimo bendrojo lavinimo mokykloje modeli.

Ekspertų vertinimo metodikos imti sudare 20 ekspertu, kurie susipažino su parengtu modeliu ir išsake savo pastebejjimus. Atrinkti keturių kategorijų asmenys, iš viso 20 ekspertų: penki ekspertai, dirbantys aukštosiose mokyklose ir rengiantys mokytojus, socialinius pedagogus, dalyvavusius kuriant socialinio pedagogo ir užsienio kalbų mokytojo rengimo standartus (2007); penki mokyklu vadovai, turintys ne mažesnę kaip penkerių metu vadybinio darbo patirti; penki socialiniai pedagogai, turintys ne mažesnę nei penkerių metų darbo mokykloje patirti; penki mokytojai, turintys ne mažesnę nei penkerių darbo mokykloje patirtị ir turintys auklejjamąsias klases.

Ekspertų apklausos procedūra vyko struktūrizuoto interviu forma. Ekspertams buvo pateikti atviri klausimai, apimantys socialiai atsiribojusiu mokinių igalinimo bendrojo lavinimo mokykloje modelio dalyvius, jų funkcijas ir veiklą. Ekspertu 
buvo prašoma ị kiekvieną klausimą atsakyti išsamiai išsakant savo nuomonę raštu.

Respondentų atsakymai buvo analizuojami atliekant turinio analizę.

\section{REZULTATAI}

Remiantis moksliniu tyrimu rezultatais buvo konceptualizuoti šie socialiniam atsiribojimui būdingo elgesio tipai:

Atsiskyrusio-pasyvaus elgesio tipas. Šiam elgesio tipui būdingas tylus objektu stebejjimas / tyrinejimas arba veikla atsiskyrus, orientuota labiau i konkrečius veiksmus su daiktais, bet ne i bendravimą su kitais asmenimis (suaugusiaisiais ar bendraamžiais), pavyzdžiui, piešimas, konstravimas, dèlionès, skaitymas vienumoje, žaidimas atsiskyrus. Vakarų šalių mokslininkai nurodo, kad ši elgesio tipa galimą pastebèti jau ankstyvojoje vaikystèje. Minètu amžiaus tarpsniu atsiskyręspasyvus elgesys pasireiškia visišku nesidomejjimu socialine sąveika su kitais (Coplan, Rubin, 1998).

Atsiskyrusio-aktyvaus elgesio tipas. Atsiskyręs-aktyvus tipas mokslininkų yra siejamas su bendraamžių atstūmimu ir socialiniu neprisitaikymu ankstyvojoje ir viduriniojoje vaikysteje, vèlesniais amžiaus tarpsniais (Ladd, Troop-Gordon, 2003). Šis tipas apibrezžiamas, kaip aktyvus veikimas atsiskyrus su arba be objektų, pavyzdžiui, vaidmenu atlikimas ,igarsinant“ žaislus, daiktus ir įsivaizduojant, kad jie yra gyvi. Mokiniai, kuriems būdingas minètas elgesio tipas, veikdami (žaisdami) bendraamžių grupèje, dažniausiai renkasi „būti“ kažkuo išskirtiniu (lyderiu, vadovu), vaidmeninių žaidimų metu renkasi vaidmenis, kuriems atlikti nereikia sąveikos (bendradarbiavimo) su kitais, pavyzdžiui, vairuotojo, lèktuvo piloto, gydytojo ir pan.). Ši tipą daugelis tyrèjų apibūdina kaip „veikianti vienumoje“, ir dèl to bendraamžiu suvokiamą kaip nedraugišką ar netgi agresyvų. Pažymima, kad véliau tai gali būti nebrandumo, impulsyvumo, bendraamžių atstūmimo priežastimi ir socialiniu neprisitaikymu (Coplan, Rubin, 1998; Hart et al., 2000).

Uždaro elgesio tipas. Dažniausiai pastebima šiam tipui būdinga elgsena yra kitu stebèjimas iš suvokiamo „saugaus“ atstumo. Tyrejai pastebi, kad šiam tipui taip pat būdinga socialinè baimè ir nerimas tiek pažistamoje, tiek nepažistamoje aplinkoje (Coplan et al., 1994; Coplan, Rubin, 1998). Šis tipas apibūdinamas kaip „būnantis vienumoje“ ir, kaip pažymi daugelis tyrejuu, rodo konfliktą tarp socialinio aktyvinimo ir vengimo motyvacijos. Ankstyvojoje vaikysteje šis tipas siejamas su nerimastingumu ir baikštumu bendraujant su nepažistamais bendraamžiais (Coplan et al., 1994), su bendraamžių atstūmimu (Rubin, Coplan, 1994), su silpnu gebejjimu reguliuoti neigiamas emocijas (Rubin, Coplan, 2004), su vidiniais sutrikimais ir motinos drovumu tiek pažistamoje, teik nepažístamoje aplinkoje (Coplan et al., 1994; Coplan, Rubin, 1998).

Socialiai atsiribojusių mokinių igalinimo teorinės prielaidos bendrojo lavinimo mokykloje. Socialinis igalinimas ir bendruomene. Vykstant pasaulio globalizacijai iškyla būtinybè analizuoti, vertinti, interpretuoti ir keisti socialinę aplinką multidisciplininiu lygiu, pasitelkiant tiek interpersonalinę, tiek aplinkos sistemas. Socialiniu tyrimu aprašymuose, monografijose ir vadovèliuose vis dažniau randame terminu, apibrèžiančiu visą socialinių mokslų sritị, tokių kaip: žmonių ištekliai, žmogaus geografija, socialinè (žmogaus, bendruomenès) ekologija, socialinis (žmogaus) kapitalas, sveikatos kapitalas, socialinė atskirtis, gyventoju kokybè, žmogaus laiko vertė ir pan. Visų šių sąvokų neaptarsime, tačiau nagrinėdami vaikų socialinio atsiribojimo problemą neišvengiamai su dauguma jų susidursime. Mes gyvename ivvairių sistemų apsuptyje. Kai kurių sistemų ryšiai yra labai glaudūs, kai kurių mažiau susiję. A. Šerkšnas teige, kad atskiro individo negalima laikyti mechaniška bendruomenès dalimi, tačiau reikia isidemèti, kad kiekviena bendruomenè, visuomenè susideda iš individų ir nèra tokio bendruomenès tikslo, kuris pirmiau būtų nebuvęs individo tikslu, ir kiekvienas atskiras individas yra tautos dvasios reiškejjas. A. Šerkšnas (1933) ypač akcentavo glaudu bendruomenès ir individo tarpusavio priklausomybès ryši. Kiekvienas atskiras individas yra tos bendruomenés (mokiniu klasés) narys, tai drauge jis yra ir kito asmens visapusiškos raidos sqlyga; tik tokia bendruomenè, kuria remiantis galima parengti žmogu ateities bendruomeniniam gyvenimui, gali funkcionuoti kaip dvasiškai koncentruota ir sutelkta bendruomenè.

Bendruomenè neatsiejamas žmonių socialinès jungties elementas, skatinantis socializacija bendraja prasme. Socializacija yra individo tapimas visuomenès neatsiejama dalimi, asmenybe; pagrindiniai socializacijos mechanizmai - mègdžiojimas, ittaiga, konformizmas, sąmoningas sekimas pavyzdžiais, visuomenès komunikavimo priemonių ir kultūros poveikis, tai visuomeniškai 
kryptingos asmenybès formavimas per kryptinga ugdymą ir aplinkos veiksnius (Bitinas, 1999).

Vaikai jau ankstyvoje vaikystejje isitraukia $\mathfrak{i}$ ¿̇vairias grupes, kai kurios jų tampa bendruomeninèmis (vaikų darželio, mokyklos, klasès). Klase, vaiku grupe turi esminiu bendruomenès bruožu ir yra didžiausios svarbos lavinant pilietinius ipročius ir savybes, siekiant itraukti i socialini gyvenima mokinius, kurie yra linke atsiriboti, atsiskirti, yra uždari, drovūs, perdètai kuklūs.

Socialinis igalinimas ir mokytojo asmeny$b \dot{e}$. Mokyklos modernizavimo požiūriu, viena iš svarbiausiu grandžiu yra mokytojo asmenybès ypatumai, kuriuos Lietuvoje linkstama analizuoti ir tyrinèti remiantis humanistinès psichologijos principais. Kartu neatmetama galimybè, kad humanistinès psichologijos plètrai didelę itaką padare individualiosios psichologijos idejos apie asmenybės vientisumą, tikslingumą, kūrybiškumą (Watts, 1996). Pagrindiniai A. Adlerio ir jo sekejų teiginiai skirti vaiku ir jų tèvų bei mokytoju auklëjimui, kad pastarieji savo poveikiu vaikams parengtu juos adekvačiai prisitaikyti prie visuomenès reikalavimų (Dreikurs et al., 1982; Pryor, Tolleruci, 1999). Individualiosios psichologijos duomenimis, vientisos asmenybès raidos pagrindas yra dinamiškas, tikslingas pranašumo siekis, atsirandantis dèl igimto nevisavertiškumo jausmo (Adleris, 2003). Šis jausmas skatina individą iveikti sunkias situacijas, aplinkybes, savo neigiamas asmenybės savybes arba daryti poveiki kitiems žmonėms. Pranašumo siekiui tinkamą krypti suteikia bendrystès jausmas. Šių dvieju pagrindinių asmenybès skatulių vedinas žmogus ir egzistuoja sociume. Manydamas, kad asmenybės branduolys susiformuoja ikimokyklinio amžiaus tarpsniu, A. Adleris (2003) išskirtini dèmesị skiria šiam amžiui reikalingam pedagoginiam poveikiui, kuris nukreipia nevisavertiškumo jausmo kompensacijos mechanizmą socialiai naudinga kryptimi. Tačiau tam, kad būtu galima organizuoti adekvatu poveiki vaiko asmenybės raidai, patys ugdytojai turètų būti „naudingoje“ gyvenimo pusèje, t. y. savo nevisavertiškumo jausmo kompensavimą grịstų išskleistu bendrystés jausmu. A. Adleris buvo įsitikinęs, kad tèvu padarytas klaidas auklèjant vaikus šeimoje turètu taisyti mokykla. Todèl ypač daug dèmesio skyrè profesiniam mokytojų, auklètojų rengimui ir jų asmenybès ugdymui, nes pedagogo profesija gali tapti nevisavertiškumo jausmo kompensacija vaikų sąskaita. Tai savo ruožtu gali trikdyti visavertès vaiko asmenybès raidą ir būti vaikams netinkamo nevisavertiškumo kompensavimo modeliu (Dreikurs et al., 1982; Pryor, Tolleruci, 1999).

Nevisavertiškumo jausmas ir pranašumo siekis yra du priešingi poliai tapačios bendros tendencijos, kurią A. Adleris dažnai vadina siekiu ivveikti nevisavertiškumo jausmo situaciją ir pasiekti pranašumo jausmą (Adleris, 2003). Pranašumo siekis visada yra nevisavertiškumo jausmo kompensacija. Šis jausmas išreiškia specifini savo vietos pasaulyje išgyvenimą, kuris persmelkia visą asmenybę ir skatina jos tobulèjimo raida. Pranašumo siekis aktyvina žmogu ir rodo jo individualią prigimti (Adleris, 2003). Bendrystės jausmas pranašumo siekiui suteikia krypti, o ją lemia visuomeninè žmogaus prigimtis (Adleris, 2003). A. Adlerio teigimu, bendrystės jausmo galimybė yra igimta, tačiau jo sklaida priklauso nuo aplinkos, visų pirma šeimos poveikio. Bendrystès jausmas taip pat universalus ir pasireiškia nuolatine, teigiama nuostata kitų žmonių atžvilgiu, nesąlygišku palankumu kitiems, rūpinimusi kitais ir noru jiems gero. Bendrystès jausmo aspektas: socialinis interesas išreiškia aktyvią, socialiai naudingą sąveiką su žmonėmis.

Bendrystès jausmo (kartu ir socialinio intereso) sunku išmokti, bet kai pedagogas ji patiria profesinio ir asmeninio bendravimo metu, tai gali kryptingai skleisti igimto bendrystès jausmo pradmenis. Mokiniai, bendraudami su tokiais pedagogais, patiria ju nuoširdu doméjimasi, supratima, rūpestí ir patys tampa gebančiais domètis, suprantančiais kitus ir jiems padedančiais, t. y. skleidžia savo socialiní interesa, ypač tada, kai šeimos auklejimo aplinka ribojo ju sklaida. Taigi išskleistas socialinis interesas yra pageidautina pedagogo savybe, norint igalinti socialiai atsiribojusius mokinius.

Socialinis igalinimas bendraamžiu grupejje. Paauglys, pereidamas nuo sajungos su šeima prie stipresnių ryšiu su bendraamžiais, igyja daugiau nepriklausomybès, paauglys nori vis daugiau priimti bendraamžiu vertybių, siekia kažką drauge veikti. Bendraamžiai labai veikia paauglio socialini gyvenimą, todèl kai kurie autoriai kalba apie atskirą paauglių visuomenę.

Paaugliu grupių fenomenas daugelyje visuomeniu yra universalus. Jos egzistuoja Vakaru ir Rytų šalyse. Paauglio santykiai šeimoje labai svarbūs, nes kuo jie blogesni tuo paaugli labiau veikia bendraamžiai.

Paauglių grupes galima skirstyti i artimų (2-9 žmonių) ir i platesnę grupę, kurią sudaro geri pažistami (15-30). Platesnèje grupeje pradeda bendrauti priešingų lyčiu paaugliai. 


\begin{tabular}{|c|c|c|}
\hline Dalyvis & Veikla & \multirow{7}{*}{$\begin{array}{l}\text { Lentelè. SAM igalinimo } \\
\text { proceso dalyvių veikla }\end{array}$} \\
\hline $\begin{array}{l}\text { Socialinis pedagogas } \\
\text { (ir SPP komanda) }\end{array}$ & $\begin{array}{l}\text { Telkti mokytojus ir klasių vadovus bendrai veiklai, t. y. organizuoti moky- } \\
\text { mus ir susirinkimus veiklai ir rezultatams aptarti. }\end{array}$ & \\
\hline Klasės auklėtojai & $\begin{array}{l}\text { Telkti socialiai aktyvius mokinius (lyderius, turinčius aukštą socialini sta- } \\
\text { tusą, kuriuos, remiantis sociometrinio testo rezultatais, rinkosi SAM) ir jų } \\
\text { tėvus, t. y. organizuoti lyderių veiklą pamokų ir nepamokinès veiklos metu } \\
\text { taip, kad kartu būtų itraukiami socialiai atsiriboję mokiniai. }\end{array}$ & \\
\hline Mokytojai & $\begin{array}{l}\text { Telkti socialiai aktyvius mokinius (lyderius, turinčius aukštą socialinị } \\
\text { statusą, kuriuos, remiantis sociometrinio testo rezultatais, rinkosi SAM), } \\
\text { t. y. organizuoti lyderių veiklą po pamokų taip, kad kartu būtų įtraukiami } \\
\text { socialiai atsiriboję mokiniai. }\end{array}$ & \\
\hline $\begin{array}{l}\text { Klasės mokiniai įžaidèjai } \\
\text { (SAM pasirinktieji pagal } \\
\text { visus kriterijus) }\end{array}$ & $\begin{array}{l}\text { Pamokų ir nepamokinès veiklos metu savo veiksmais nuolat įtraukti į } \\
\text { bendrą veiklą atsiribojusius mokinius, t. y. kartu atlikti mokytojo skirtas } \\
\text { užduotis, kartu užsiimti mėgstama veikla, kviesti juos i̇ savo susibūrimus, } \\
\text { skatinti juos kalbėti ir pasakoti apie save ir savo pomėgius. }\end{array}$ & \\
\hline $\begin{array}{l}\text { SAM tėvai (ir kiti jų } \\
\text { šeimos nariai) }\end{array}$ & $\begin{array}{l}\text { Skatinti SAM ir mokinių ižaidèjų bendravimą nepamokinės veiklos metu } \\
\text { (ruošiant namų darbus, laisvalaikiu ir pan.). }\end{array}$ & \\
\hline $\begin{array}{l}\text { Mokinių ižaidejų tèvai } \\
\text { (ir kiti jų šeimos nariai) }\end{array}$ & $\begin{array}{l}\text { Skatinti SAM ir mokinių ižaidèjų bendravimą nepamokinės veiklos metu } \\
\text { (ruošiant namų darbus, laisvalaikiu ir pan.). }\end{array}$ & \\
\hline
\end{tabular}

Paauglių tapsmui bendravimas bendraamžių grupeje yra labai svarbus igyjant socialinę patirti, laisvejjant nuo šeimos, formuojant individualia pažiūrų sistemą. Paauglys, nepriimtas i̇ grupę (izoliuotas ar atstumtas), patiria neigimas emocijas, prastą savęs vertinimą ir pan. Todèl nepaprastai svarbu išryškinti teigiamas jo savybes, ugdyti pasitikejjimą savimi, ruošti integracijai i bendraamžių būrí.

L. B. Rosenfeld ir kt. (2000) tyrè pagrindinès mokyklos moksleivių socialinio palaikymo tinklo, t. y. tėvų, mokytojų, draugų, itaką mokinių pažangumui, lankomumui ir elgesio problemoms mokykloje. Tyrimo rezultatai parode, kad mokiniai, prastai vertinę tėvų, mokytojų ir draugų socialini palaikymą, turèjo blogus mokyklos pasiekimų rodiklius. Palyginus moksleivius, kurie puikiai vertino tik vieno ar dviejų palaikymo teikèju parama, su moksleiviais, kurie vertino visų trijų palaikymo teikèju parama, paaiškejjo, kad antros grupès moksleiviu elgesys ir lankomumas geresni, jie daugiau laiko skiria namų darbams, yra labiau patenkinti mokykla, geriau vertina save, geresni ir jų pažymiai. Kaip socialinis palaikymas pozityviai veikia mokini, aiškinama ịvairiai. J. D. Coie (1993) ir kiti tyrèjai mano, kad socialinis palaikymas apskritai prisideda prie vaiko raidos bei jo prisitaikymo mokykloje ir yra apsauginis veiksnys, nes tyrimai rodo, kad vaikai, esantys rizikos grupeje, gauna mažiau socialinio palaikymo nei kiti. Mokyklos ir tėvų bendradarbiavimo svarba pabrèžiama tiek Lietuvos, tiek užsienio autorių darbuose.

Vakarų šalių mokslininkai atliko nemažai tyrimų, analizuojančių teigiamą bendraamžių poveiki mokyklinio amžiaus tarpsniu (Moroz; Jones, 2002;
Fantuzo et al., 2005 b, 2006, 2007). K. B. Moroz ir K. M. Jones (2002) tyrimu rezultatai taip pat atskleide pozityvu bendraamžiu poveiki (angl. Pozitive Peer Reporting - PPR) siekiant socialiai igalinti atsiribojusius mokinius bendrojo lavinimo mokyklos kasdienineje klasès veikloje.

J. Fantuzo ir kt. (2005 a) tyrè socialiai aktyviu mokinių, kaip bendravimo „skatintoju““, poveiki uždariems mokiniams. Socialiai aktyvūs vaikai, tarp bendraamžių pripažistami lyderiais, mokytojų buvo skatinami i veiklą įtraukti uždarus, atsiribojusius bendraamžius. Mokytojų ir klasių vadovų skatinami jie pamoku, nepamokinès veiklos metu savo veiksmais atsiribojusius mokinius nuolat itraukia i bendrą veiklą, t. y. kviečia juos kartu atlikti mokytojo skirtas užduotis, kartu užsiimti mėgstama veikla, kviečia juos ị savo susibūrimus, skatina kalbetti ir pasakoti apie save, savo pomėgius, siūlosi kartu su jais užsiimti mėgstama veikla. Mokytojo vaidmuo čia yra telkti socialiai aktyvius mokinius (lyderius, turinčius aukštą socialini statusą), organizuoti lyderių veiklą pamoku ir nepamokinès veiklos metu taip, kad kartu būtu itraukiami socialiai atsiriboję mokiniai. J. Fantuzo ir kt. (2005) ši socialinio igalinimo metodą pavadino „, Grįžtamuoju bendraamžiu poveikiu“ (,Resilient Peer Treatment “ (RTP). J. Fantuzo ir kt. (2005) pastebejo, kad taikant toki socialinio igalinimo metodą tiek laboratorinèmis, tiek natūraliomis mokyklinio gyvenimo sąlygomis socialiai atsiribojusių afroamerikiečių vaikų elgesyje labai sutrumpejjo laikas, kuri jie praleidžia vieni, pailgejjo bendros veiklos laikas ir padaugejjo kontaktu su bendraamžiais, sumažejo atsisakymų kartu užsiimti bendra veikla su bendraamžiais. Remdamiesi 
Pav. Socialiai atsiribojusių mokinių igalinimo bendrojo lavinimo mokykloje modelis

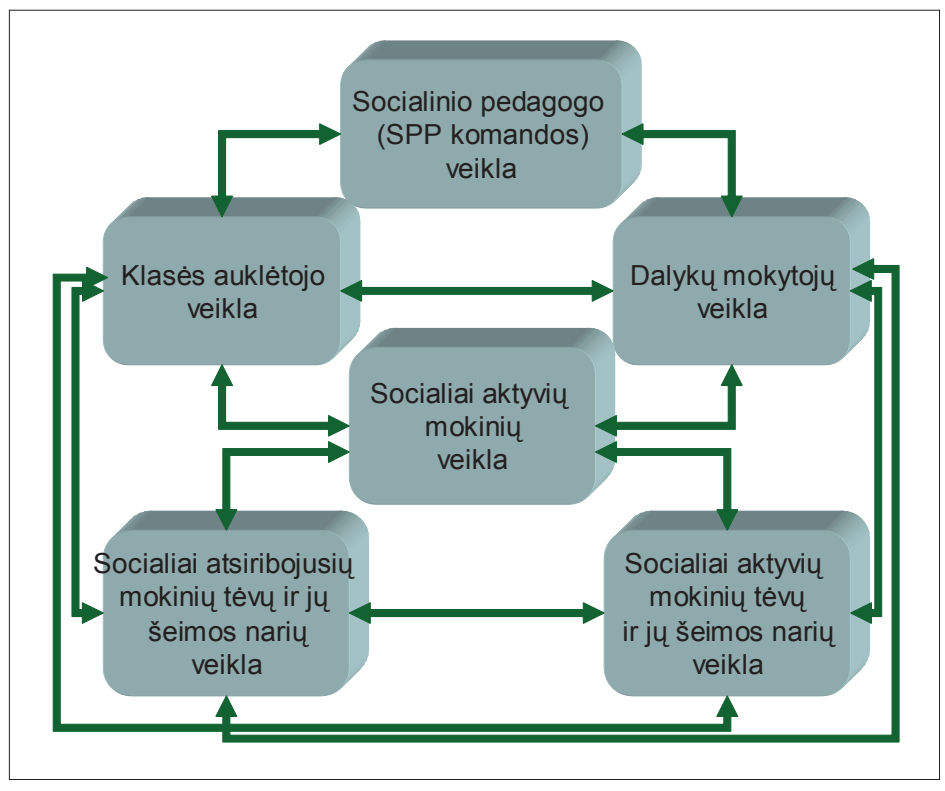

minètų tyrimų rezultatais, mokslininkai iškèlę hipotezę, kad RTP metodas galètų būti tinkamas ivvairių socialinių grupių ir kultūrų socialiai atsiribojusių vaiku igalinimui.

Socialiai atsiribojusių mokinių igalinimo bendrojo lavinimo mokykloje teorinis modelis. Remiantis teorine analize išskirti socialiai atsiribojusių mokinių igalinimo bendrojo lavinimo mokykloje proceso dalyviai, apibrèžtos jų funkcijos ir veikla, nukreipta vieno tikslo link, t. y. siekianti sukurti tinkamą socialiai atsiribojusius mokinius igalinančią aplinką bendrojo lavinimo mokykloje (žr. lentelę).

Apibrèžus socialiai atsiribojusių mokinių igalinimo proceso bendrojo lavinimo mokykloje dalyvius, jų funkcijas ir veiklą buvo numatyti visų dalyvių tarpusavio ryšiai bei sukonstruotas teorinis socialiai atsiribojusių mokinių igalinimo bendrojo lavinimo mokykloje modelis (žr. pav.).

Ekspertinis vertinimas. Analizuojant ekspertų išsakytus teiginius paaiškejjo, kad respondentų nuomonè iš esmès vieninga. Ekspertai teigè, kad socialiai uždarų mokinių igalinimo procesą turi inicijuoti socialinis pedagogas kartu su klasès auklètoju ir mokytojais, papildomojo ugdymo mokytojais, visa mokyklos bendruomene todèl, kad vaiko socializacija bus sèkminga tik dirbant komandinị darbą. Tokią apklaustujų nuomonę patvirtina išsakytieji teiginiai: „mano manymu, socialiai uždarų mokinių igalinimo procesą turi inicijuoti socialinis pedagogas kartu su klasès auklètoju ir mokytojais“; ,,atsakingas turètú būti klasès auklètojas, nes jo pareiga rūpintis, kad auklètiniai jaustųsi visaverčiais klasès mokiniais. Labai svarbu pedagogams bendradarbiauti, kad būtų pasiekti geriausi rezultatai, užsibrèžti tikslai“; „už socialiai atsiribojusio mokinio igalinimą turi būti atsakinga visa pedagoginè ir psichologine mokytojų komanda, nes būtent ji vykdytu igalinimo procesą“; „turètų inicijuoti psichologinès ir pedagoginès komandos nariai, o atsakinga už šio proceso veiksmingumą yra visa mokyklos bendruomenè. Tokia pagalba būtų veiksmingesnè ir pačiu laiku“; ,klasès auklètojas, socialinis pedagogas, psichologas, papildomojo ugdymo mokytojas, visa mokyklos bendruomenè taip pat tėvai. Vaiko socializacija bus sėkminga dirbant komandini darbą".

Ekspertai vieningai teigè, kad visų dalyvių funkcijas turètų nustatyti psichologinè-pedagoginè komanda; jos narius turètú vienyti bendrų tikslų siekimas. Tai patvirtina tokie apklaustujų teiginiai, kaip antai: „norint pasiekti gerų rezultatų, reikia visiems dalyviams veikti išvien, kad procesas nenutrūktų“; ,visi dalyviai privalètų turèti bendrus tikslus, kurių per visą igalinimo procesą siektų“; „dalyvius turètú vienyti bendra veikla, tik vieninga, bendradarbiaujanti komanda galètų pasiekti užsibrèžtus tikslus“; ,,socialinè-pedagoginè komanda, rengdama planą, numato, kokias funkcijas atliks specialistai, klasių auklètojai, dalykų mokytojai ir kt.“; „,klasès auklètojo funkcija — vaiko aktyvinimas, ittraukimas ị klasès veiklą, organizavimą, darbą, žaidimų organizavimą, kurie skatina bendravimą ir bendradarbiavima, dalyko mokytojo aktyvių mokymo metodų propagavimas, socialinio pedagogo — vaiku itraukimas i projektinę veiklą ir pan., mokyklos administracijos — parengti programą „Darbas su socialiai uždarais mokiniais“ (integruotą, komandinị, projektini darbą pateikia ivairiomis metodinèmis rekomendacijomis, pareigybių instrukcijomis ir pan.) ${ }^{6 ،}$. 
Ekspertai išreiškė nuomonę, kad aktyvūs mokiniai turètų daugiausia įtakos socialiai uždariems, kad jie galètu būti igalinimo proceso dalyviais ir turètų ne tik dalyvauti veikloje, bet ir ją organizuoti, planuoti. Tai įrodo išsakyti teiginiai: „Aktyvūs mokiniai galètų patraukti savo veiklon socialiai uždarus mokinius; taip jie galètų tapti igalinimo proceso dalyviais“. „Pamokyti juos galètų socialinis pedagogas, nes, manau, kad socialinis pedagogas gali kompetentingiau atlikti ši mokymą, o dèl įtraukimo í veiklą didesnè atsakomybè tektu auklètojams ir dalykų mokytojams“; ,manau, kad būtu imanoma ši veikla. Tai, ko gero, ir būtu vienas iš problemos sprendimo variantu“"; „manau, kad būtent tokie mokiniai turètų daugiausia įtakos socialiai uždariems mokiniams, nes mokiniams didžiausią itaką daro bendraamžiai“; ,,mokinius turètų būtinai mokyti specialistai, taip pat i ši procesą turetų būti ittraukti ir dalykų mokytojai“; „labai veiksmingas metodas „Bendraamžiai bendraamžiams“; „draugų pagalba gali būti daug veiksmingesnè nei suaugusių žmonių“; , ,aktyvesni mokiniai turetu būti ne tik itraukiami i veiklą, bet ir i jos organizavimą, planavimą“; ,aktyvesni mokiniai turi būti nuolat ịtraukiami ị socialinę veiklą, nes jie ne tik patys tobulès, bet ir padès aplinkiniams, ne tokiems aktyviems mokiniams".

\section{REZULTATŲ APTARIMAS}

Atlikta teorinè analizè ir ekspertu vertinimas parodè, kad:

- socialiai atsiribojusių mokinių igalinimą turètų inicijuoti: psichologinès-pedagoginès komandos nariai kartu su socialiniu pedagogu, itraukdami dalykų mokytojus, klasių auklètojus; turètų būti rengiami planai, užsibrèžiami tikslai, o visus proceso dalyvius turi sieti vieningai organizuota veikla;

- klasè, vaiku grupe turi esminių bendruomenès bruožų ir yra labai svarbi lavinant pilietinius ipročius ir savybes, siekiant itraukti i socialini gyvenimą mokinius, kurie yra linkę atsiriboti, atsiskirti, yra uždari, drovūs, perdètai kuklūs;

- socialiai atsiribojusių mokiniu socialinio igalinimo bendrojo lavinimo mokykloje paveikiais proceso dalyviais galètu būti socialiai aktyvūs bendraamžiai. Aktyvių mokinių bendravimas, bendradarbiavimas su socialiai atsiribojusiais mokiniais yra veiksmingesnis sprendžiant įtakos klausimą nei suaugusiujų. Aktyvių mokinių mokymą turètų organizuoti socialiniai pedagogai, tos srities specialistai.

- socialiai atsiribojusių mokinių socialinio igalinimo bendrojo lavinimo mokykloje paveikiais proceso dalyviais turi būti mokiniu tèvai ir kiti šeimos nariai.

Apibendrinant atliktą teorinę analizę ir ekspertinio vertinimo rezultatus svarbu pabrèžti, kad norint taikyti mokyklinejje praktikoje sukonstruotą teorini socialiai atsiribojusių mokiniu igalinimo modeli, pirmiausia būtina ji patikrinti eksperimentiniu arba veiklos tyrimu.

\section{IŠVADOS}

1. Socialinio atsiribojimo sąvoką apibūdiname kaip tam tikrą vaiko ar paauglio elgesenos modeli, pagal kuri vaikas nuolat vengia bet kokios sąveikos su bendraamžiais ar jų grupèmis jam gerai pažistamomis situacijomis.

2. Socialiai atsiriboti linkę (uždari) mokiniai gali būti atskirti kitu arba dèl gyvenime susiklosčiusių aplinkybių, kurios nesuteikia jiems strategijų sėkmingai socializacijai. Tai reiškia ne tik mažesnes galimybes naudotis ivvairiomis socialinėmis garantijomis ar privilegijomis, bet ir mažesnes galimybes aktyviai mokytis, dalyvauti socialinėje, vèliau ir profesinèje veikloje.

3. Socialinis igalinimas skiriamas socialiniam funkcionavimui gerinti suteikiant socialinę (aktyvaus bendravimo ir bendradarbiavimo) parama.

4. Klasè, vaiku grupé turi esminių bendruomenès bruožuc ir yra labai svarbi lavinant pilietinius ipročius bei savybes, siekiant įtraukti i socialini gyvenimą mokinius, kurie yra linkę atsiriboti, atsiskirti, yra uždari, drovūs, perdètai kuklūs.

5. Socialiai atsiribojusių mokinių igalinimą turètu inicijuoti: psichologinès-pedagoginès komandos nariai kartu su socialiniu pedagogu, itraukdami dalykų mokytojus, klasių auklètojus; turètų būti rengiami planai, užsibrèžiami tikslai, o visus proceso dalyvius turètu sieti vieningai organizuota veikla.

6. Socialiai atsiribojusių mokiniu socialinio igalinimo bendrojo lavinimo mokykloje paveikiais proceso dalyviais galètų būti socialiai aktyvūs bendraamžiai ir ju tèvai, socialiai atsiribojusiu mokinių tèvai. Aktyvių mokinių bendravimas, bendradarbiavimas su socialiai atsiribojusiais mokiniais yra veiksmingesnis sprendžiant itakos klausimą nei suaugusiujų. Aktyvių mokiniu mokymą turètų organizuoti socialiniai pedagogai, tos srities specialistai. 


\section{LITERATŪRA}

Adleris, A. ( 2003). Žmogaus pažinimas. Vilnius. Bitinas, B. (1999). Ugdymo filosofijos pagrindai. Vilnius. P. 79 .

Coie, J. D., Watt, N. F., West, S. G. et al. (1993). The science of prevention: A conceptual framework and some directions for a National Research Program. American Psychologist, 48, 1013-1022.

Coplan, R. J., Rubin, K. H. (1998). Exploring and assessing nonsocial play in the preschool. The development and validation of the preschool play behavior scale. Social Development, 7, 72-91.

Coplan, R. J., Rubin, K. H., Fox N. A., Calkins, S. D., Stewart, S. L. (1994). Being alone, playing alone, and acting alone: Distinguishing among reticence, and passive- and active-solitude in young children. Child Development, 65, $129-137$.

Cornwall, J. R., Perlman, B. (1990). Organisational Entrepreneurship. Boston: IRWIN.

Dabartinès lietuviu kalbos žodynas. (1993). Vilnius: Mokslo ir enciklopedijų leidykla. P. 203.

Dreikurs, R. and others (1982). Maintaining Sanity in the Classroom. Bristol.

Fantuzzo, J., Bulotsky-Shearer ,R., McDermott, P. et al. (2007). Investigation of dimensions of social-emotional classroom behavior and school readiness for low-income urban preschool children. School Psychology Review, 36, $44-62$

Fantuzzo, J., Manz, P., Atkins, M., Meyers, R. (2005 a). Peer-mediated treatment of socially withdrawn maltreated preschool children: Cultivating natural community resources. Journal of Clinical Child and Adolescent Psychology, 34, 322-327.

Fantuzzo, J., Perlman, S. (2007). The unique impact of out of home placement and the mediating effects of child maltreatment and homelessness on early school success. Children and Youth Services Review, 29, 941-960.

Fantuzzo, J., Perry, M., Childs, S. (2006 a). Parent satisfaction with educational experiences scale: A multivariate examination of parent satisfaction with early childhood programs. Early Childhood Research Quarterly, 21 (2), $142-152$.

Fantuzzo, J., Rouse, H. L., McDermott, P. et al. (2005 b). Early childhood experiences and kindergarten success: A population-based study of a large urban setting. School Psychology Review, 34 (4), 571-588.

Gerhold, M., Laucht, M., Texdorf, C., Schmidt, M. H., Esser, G. (2002) Early mother-infant interaction as a precursor to childhood social withdrawal. Child Psychiatry \& Human Development, 32 (4), 277-293.

Hart, H. C., Yang, C., Nelson, L. J. et al. (2000). Peer acceptance in early childhood and subtypes of socially withdrawn behaviour in China, Russia, and United States. International Journal of Behavioural Development, 24 (1), 73-81.

Koberg, C. S., Boss, R. W., Senjem, J. C. (1999). Antecedents and outcomes of empowerment: Empirical evidence from the health care industry. Group Organization Management: An International Journal, 1, 24, 71-91.

Ladd, G. W., Herald, S. L., Andrews, R. K. (2006). Young children's peer relations and social competence. In B. Spodek \& O. N. Saracho (Eds.), Handbook on the Education of Young Children (pp. 23-54). Hillsdale, NJ: Erlbaum.

Ladd, G. W. (2006). Peer rejection, aggressive or withdrawn behavior, and psychological maladjustment from ages 5 to 12: An examination of four predictive models. Child Development, 77 (4), 822-846.

Ladd, G. W., Troop-Gordon, W. (2003). The role of chronic peer adversity in the development of children's psychological adjustment problems. Child Development, 74, 1325-1348.

Lipinskienè, D. (2002). Edukacinè studenta igalinanti studijuoti aplinka: daktaro disertacija. Kaunas.

Malinauskienè, O., Žukauskienė, R. (2007). Paaugliu emocinių ir elgesio sunkumų sąsajos ir pokyčiai per trejus metus: amžiaus ir lyties ypatumai. Psichologija, 35, $19-31$.

Moroz, K. B., Jones, K. M. (2002). The effects of Positive Peer Reporting on children's social involvement. School Psychology Rewiew, 31 (2), 235-245.

Nelson, L. J., Hart, C. H., Robinson, C. C., Olsen, S. F., Rubin, K. H. (2000). Relations between Sociometric Status and Three Subtypes of Withdrawn Behavior in Preschool Children: A Multi-method Perspective. Manuscript submitted for publication.

Pryor, D. B., Tolleruci, T. R. (1999). Applications of Adlerian principles in school setting. Professional School Counseling, 2, 299-305.

Rosenfeld, L. B., Richman, J. M., Bowen, G. L. (2000). Social support networks, and school outcomes: The centrality of the teacher. Child and Adolescent Social Work Journal, 205-226.

Rubin, K. H., Coplan, R. (2004). Paying attention to and not neglecting social withdrawal and social isolation. Merrill-Palmer Quarterly, 50, 506-534.

Sondaitė, J., Žukauskienè, R. (2004). Paauglių socialinès strategijos ir emocinès elgesio problemos. Psichologija, 29, 106-114.

Šerkšnas, A. (1933). Mokyklinè bendruomene: praktinès pedagogikos studijos. Kaunas. P. 140.

Thorlakson, A. J. H., Murray, R. P. (1996). An empirical study of empowerment in the workplace. Group \& Organisation Management, 1, 21, 67-83.

Usher, R., Bryant, J., Johnston, R. (1997). Adult Education and the Postmodern Challenge: Learning Beyond the Limits. London: Routledge.

Watts, R. E. (1996). Social interest and the core conditions: Could it be that Adler influenced Rogers. Journal of Humanistic Counselling, Education and Development, 34, 165-171. 


\title{
THEORETICAL ASSUMPTIONS OF EMPOWERMENT OF SOCIALLY WITHDRAWN PUPILS AT SCHOOL
}

\author{
Laima Kyburiené $\dot{1}^{1,3}$, Donatas Senikas ${ }^{2}$, Žibuoklė Senikiené $\dot{3}^{3}$ \\ Vytautas Magnus University ${ }^{1}$, Kaunas University of Medicine ${ }^{2}$, Kaunas College $e^{3}$, \\ Kaunas, Lithuania
}

\begin{abstract}
The goal of the paper is to investigate possibilities of social empowerment for socially withdrawn pupils at school. The idea of school life completeness and harmony is emphasized as determinant of spiritual development of a person. Years spent at school enable a child to learn a lot of new things, to better understand the surrounding world and find a lot of friends. For most children who start school, the future seems challenging and full of various opportunities. They believe they can reach and conquer everything. The school, as well as friendship with their contemporaries, is very important for schoolchildren. The process of socialization (the opposite of isolation and self-isolation) during the school years actually is a complete impact of the environment on a child giving him / her an opportunity to fully indulge into the life of society.

Disassociated children who seem to be successful (good results, satisfactory behaviour) may have emotional problems: they may feel uncomfortable if they are asked to talk in front of the class, their hands tremble while speaking, their voice is very low and lamentable, and they prefer staying aloof. A high level of uneasiness is characteristic to such children. They underestimate themselves; they are easily hurt and cannot express all their abilities.

After presenting the conceptions of social empowerment and social withdrawal, the attention was focussed on possibilities of social empowerment of socially withdrawn pupils at school.

Research data collected indicates that it is theoretically possible to build a model in order to socially empower those pupils who are socially withdrawn through proper guidance concerning the developmentment of necessary social interaction skills:

- Social educators and special psychologic-pedagogical teams should initiate social empowerment programs for socially withdrawn pupils. School subject teachers should be involved in this process too.

- Class, group of peers have the main lineaments of community and also have the lighest importance in citizenship education and social empowerment of socially withdrawn pupils.

- Socially active classmates can be useful participants in the process of social empowerment of socially withdrawn pupils. Social educators and teachers must take care, however, to properly prepare socially active classmates for proper participation in this process.

- In conclusion it should be stressed that this theoretical model of social empowerment of socially withdrawn pupils at school can be used only after its verification by an experiment or an action research and further research.
\end{abstract}

Keywords: social withdrawal, social empowerment, model of empowerment. 